\title{
Unusual penetration of a construction nail through the orbit to the cranium: a case report
}

\author{
Bir inşaat çivisinin alışılmadık şekilde orbitayı geçerek kraniyuma saplanması: \\ Olgu sunumu
}

\section{İbrahim ERKUTLU, ${ }^{1}$ Mehmet ALPTEKİN, ${ }^{1}$ Mehmet DOKUR, ${ }^{2}$ Murat GEYİK, ${ }^{1}$ Abdulvahap GÖK ${ }^{1}$}

Penetrating head and neck trauma with construction nails are uncommon life-threatening injuries and an important problem in developing countries. Assessment of the neurovascular and systemic physical status is a first requirement, and the decision concerning which surgical approach to perform for the removal of the nail is of critical importance. A 10-year-old girl was presented one hour after a fall injury with complaint of a swelling and foreign body lodgment on the left forehead. Neurological and systemic physical examinations were normal except for weak direct pupillary light reflex on the left side and the patient's state of uneasiness. Radiological investigations showed that the head of the nail had entered from the left infraorbital region and become lodged through the orbital roof, below the frontal bone. Surgical extraction of the nail in the operating room was performed successfully using left pterional craniotomy and lateral orbitotomy technique, and there was no complication after surgery. Here, we report a case with a rare craniocerebral penetrating wound and type, with the head of the nail lodged in the anterior fossa through the orbital roof, which may be defined as 'reverse penetration of the nail'.

Key Words: Craniocerebral penetrating injury; nail; surgery; treatment options.
İnşaat çivileriyle oluşan delici baş ve boyun yaralanmalarl, nadiren gözlenen, ölümcül ve gelişmekte olan ülkelerin önemli bir problemidir. Hastanın nörovasküler durumu ve sistemik fiziksel incelemesi ilk bilinmesi gereken durumdur, çivinin çıkarılmasında cerrahi ve/veya medikal olarak hangi yaklaşımın uygulanacağı kritik önem taşır. On yaşında, yüksekten düştükten 1 saat sonra sol alnında şişlik ve yabancı cisim batması şikayetiyle başvuran bir kız çocuğu sunuldu. Sol göz ışık refleksindeki zayıflık ve huzursuzluğu dışında nörolojik ve sistemik muayenesi normal idi. Radyolojik araştırmalar çivi başının sol supraorbital bölgeden girdiğini ve orbital tavan boyunca ilerleyerek frontal kemiğin altından ilerleyerek saplandığını gösterdi. Çivi sol piterional kraniyotomi ve lateral orbitotomi tekniği kullanılarak başarıyla çıkarıldı ve cerrahi sonrası herhangi bir komplikasyon gelişmedi. Biz burada belkide "çivinin ters penetrasyonu" olarak tanımlanabilecek nadir bir kraniyoserebral delici yaralanmayı ve orbital tavan boyunca ilerleyerek anterior fossaya baş kısmıyla saplanan bir yaralanma tipini sunduk. Ek olarak bu tip yaralanmalarda çivi baş tarafından kraniyuma saplandıysa ameliyat öncesi ve sonraS1 alınması gereken önlem ve tedavi stratejileri tartışıışıldı.

Anahtar Sözcükler: Kraniyoserebral delici yaralanma; çivi; cerrahi; tedavi seçenekleri.
Penetrating orbito-cranial injuries are quite common in military practice, but they are very rarely seen in civilian life, where they are predominantly accidental injuries. Penetrating object injuries occurring by falling onto a penetrating object such as a nail are rarely encountered cases, although a number of head injuries associated with construction nails have been reported previously. ${ }^{[1-5]}$ These types of injuries can be life-threatening, depending on the patient's age, the injury location and vascular and other complications of the injury. ${ }^{[4,5]}$ The most common delayed complications are cerebrospinal fluid (CSF) leakage, infectious complications such as meningitis, orbital cellulitis and cerebral abscess, and vascular injuries such as traumatic aneurysm and progressive intravascular thrombosis. ${ }^{[2-4,6]}$ However, their true incidence is not clear. ${ }^{[4]}$

Due to the risk of significant neurological and vascular complications, it is important to clarify where the foreign body is located, and it is vital to determine 
the most appropriate surgical approach to remove the object and overcome potential complications.

We report a patient who fell onto a rusty nail that lodged head-first deeply into the anterior cranial fossa through the orbital roof, and we discuss the treatment strategies.

\section{CASE REPORT}

In this case presentation, we carried out the surgical analysis of a 10 -year-old female child who was admitted to our clinic from another hospital with the anamnesis of falling from a first floor height onto a rusty nail $7-8 \mathrm{~cm}$ in length, resulting in a serious lodgment into the left orbital region. Edema and a sharppointed metal object were observed on the left eyelid, protruding $0.5 \mathrm{~cm}$ from the skin. Although her verbal response was confused, she was able to obey commands for the examination. Glasgow Coma Scale was 15 (E4-M6-V5), and direct pupillary light reflex was positive in the right eye and weak in the left eye. There was no active bleeding from the wound, which was on the lateral edge of the left eyebrow (Fig. 1d). Cranial X-rays and computerized tomography (CT) showed that the nail had entered from the lateral edge of the left orbital roof. The nail head was lodged in
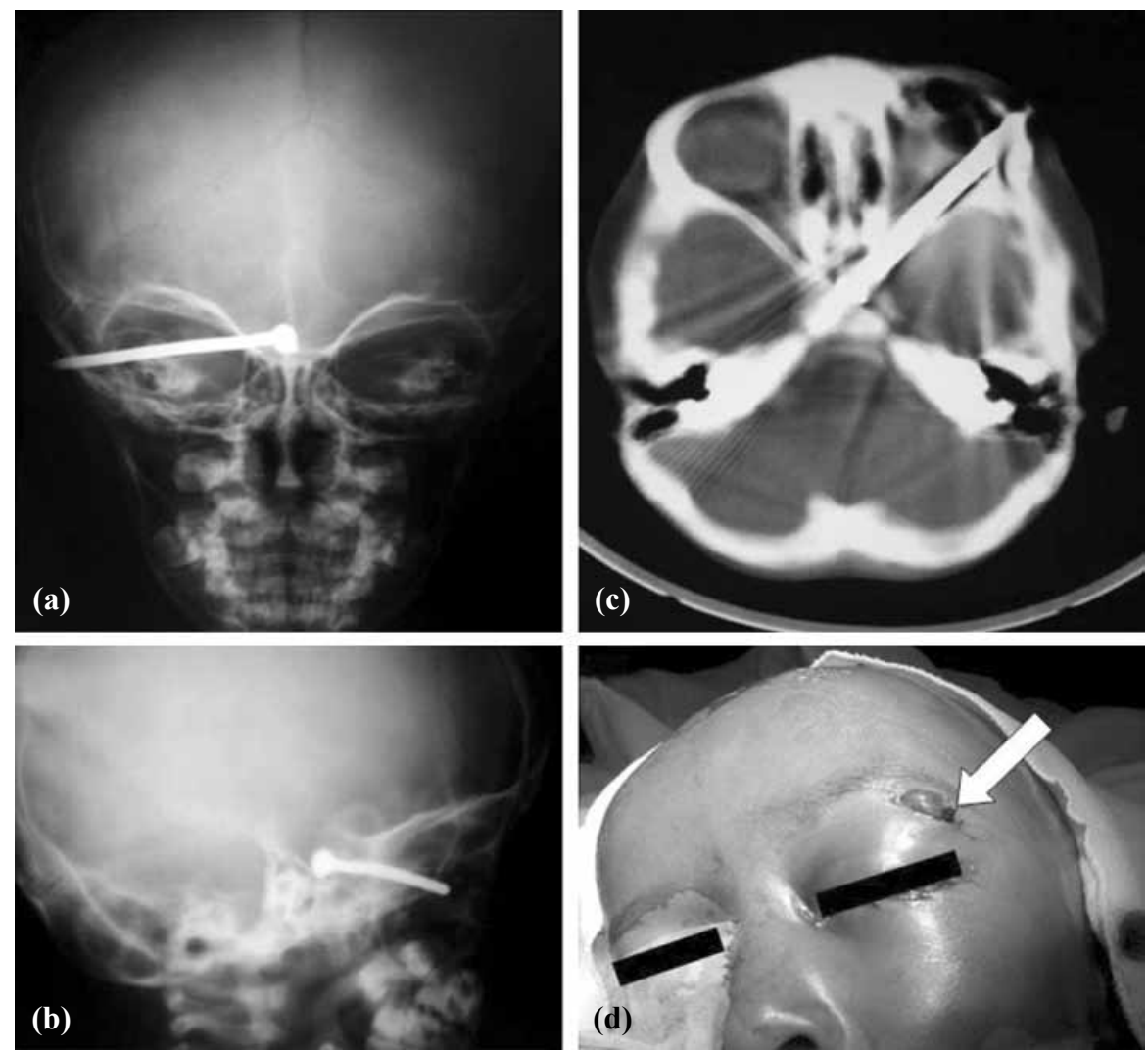

Fig. 1. Antero-posterior (a) and lateral (b) cranial plain radiographs of the patient show the nail and its location. Axial CT image shows the intracranial portion of the nail. The head of the nail was very close to the left carotid artery and optic nerve (c). Note that the sharp tip of the nail protrudes from the cranium (white arrow) (d). the left anterior cranial fossa. The head of the nail was very close to the paraophthalmic segment of the left internal carotid artery and the left optic nerve (Fig. 1ac). Since the neurological and radiological investigations showed no vascular injury, we decided to extract the nail surgically (Fig 2a-c). The patient was taken to the operating room immediately. A left pterional craniotomy was performed through a standard frontotemporal skin incision and then lateral orbitotomy was added to this approach. Following craniotomy, the nail was exposed extradurally. We observed that the head of the nail penetrated the cranium, orbital roof, periorbital adipose tissue, and dura mater. The dura was opened over the proximal sylvian fissure. After sylvian dissection, the nail was exposed intradurally and extradurally. The head of the nail was observed to press on the internal carotid artery without any penetration. Although the head of the nail was very close to the paraophthalmic segment of the left internal carotid artery and the left optic nerve, it was quite far from the pituitary gland, 3rd cranial nerve and stalk; therefore, no abnormality in pituitary functions or the 3rd cranial nerve was observed. Intraoperatively, no injury to these structures was seen. We also interpreted the cause of the pupillary dysfunction as perhaps being related to the trauma to the globe.

The patient received analgesic medication, prophylactic antibiotics and tetanus prophylaxis. She showed no additional clinical abnormality after the operation except for weak pupillary light reflex. Her follow-up cerebral CT was normal during the postoperative period (Fig. $2 d)$. She was discharged on the 7 th postoperative day.

\section{DISCUSSION}

In the literature, this type of injury has mostly been reported as nail gun injuries..$^{[1,5]}$ The foremost priority, which is critical in assessing penetrating craniocerebral injuries, is to determine if any vascular injuries have occurred and to eliminate any problem that could affect vital functions..$^{[1-3,5]}$ Many algorithms concerning diagnostic and therapeutic approaches have been published previously on this subject. ${ }^{[7]}$

We report this case for several reasons. First, the patient's 
presentation was unusual with respect to the penetration of the rusty nail, that is to say, it may be described as a "reverse penetration".

One of the interesting subjects about this trauma is how deeply the nail was able to penetrate the cranial structure. Complete penetration of nails into the cranial cavity is rather rare ${ }^{[8]}$ Similar to other studies, the entry point in our case was also the orbital roof. The orbital roof is seen in many series as the point of entry; its mechanism can be explained by patients' extending their head backwards during injury, thus exposing the orbital roof. In addition, the orbital roof is a very thin, bony plate, offering little resistance. ${ }^{[6]}$

Second, reverse penetration of the nail is very important in terms of the surgical removal. If the object is removed suddenly during surgery, it may drag the neurovascular structures together with the head of the nail and may cause fatal injuries. This situation forms the important distinction between the present case and the more common types of injuries where the nail lodges tip-first.

Treatment of penetrating craniocerebral wounds with nails at the skull base is problematic, due to difficulties regarding surgical exposure. The anterior fossa contains important neurovascular structures such as the internal carotid artery and branches, the optic nerve and orbital structures. ${ }^{[9]}$ If it is possible, and had
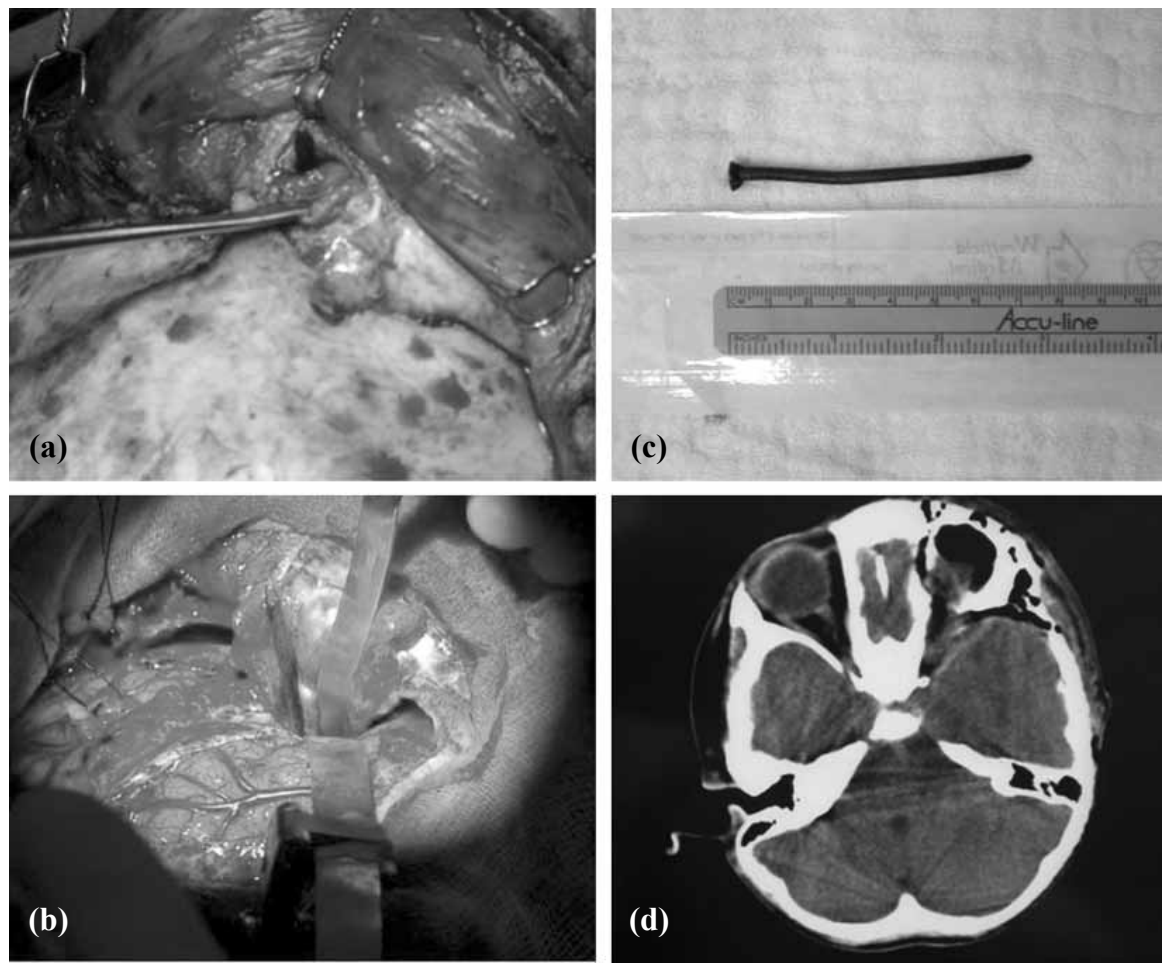

Fig. 2. Intraoperative images show cranio-orbital approach (a) and the nail located between the left periorbita and the sylvian fissure (b). The nail was $7-8 \mathrm{~cm}$ in length (c). Early postoperative axial CT image demonstrates that there was no lesion in the surgical area (d). the patient exhibited signs of vascular injury, vascular monitoring in the neck and even proximal-distal monitoring intracranially would have been required. Trauma to the cerebrovascular system (both penetrating and non-penetrating) can cause injuries such as arterial dissection, pseudoaneurysm, arterial or venous rupture or thrombosis, and arteriovenous fistula. ${ }^{[10]}$ Angiography should be immediately performed, and any probable vascular damages should be investigated. If the lesion caused by the penetrating object has already affected the venous structures, the patient unquestionably should be evaluated by preoperative angiography, CT and/or magnetic resonance imaging (MRI) due to the potential for an unexpected air embolism..$^{[2,3,8]}$ Postoperatively, a second vascular study should always follow 2-3 weeks after a negative one to detect the possibility of the formation of a pseudoaneurysm. ${ }^{[2,4,5]}$ The guidelines for the management of these aneurysms are not well defined, especially with regards to asymptomatic patients. There are several different methods for the management of these injuries. ${ }^{[4]} \mathrm{A}$ foreign body that has completely penetrated into the brain needs to be removed via craniotomy. Some authors have advised that if angiography is negative for vascular injury and the patient is asymptomatic, the nail should be extracted via closed gentle traction. They also have advocated that intervention involving craniotomy and/or an endovascular approach should be reserved for those presenting with symptoms of vascular involvement and also when the nail has no extracranial extension, due to possible unnecessary complications. ${ }^{[7,9,11]}$

Third, the priority is selection of the most logical treatment strategy to overcome these injuries. Many authors have advised previously that the most appropriate treatment in cerebral penetrating injuries is surgical intervention, if possible. ${ }^{[8]}$ At this point, the question remains: what should we do or which treatment strategy should we choose if the vascular injury is beyond repair? In this problematic situation, endovascular management or extracranial-intracranial vascular bypass procedures would have had to be considered. ${ }^{[9]}$ There was no injury to the neurovascular structures in our case because of blunt compression by the head of the 
nail. However, we believe that, in cases of penetrating cranium injuries, the object should be removed in the operating room due to the high risks of neurovascular injury. One of the most important reasons for neurovascular injury during surgery is a wrongly selected or inadequate surgical approach. A wide surgical exposure along with careful manipulation of the embedded nail is of importance to avoid unexpected injury to the surrounding brain and related structures. The cranio-orbital approach has been used for many years to treat some vascular and tumoral lesions in neurosurgical practice. This technique also provides a wide and safe surgical corridor in anterior fossa lesions and necessitates less retraction of the vital neurovascular structures. ${ }^{[12,13]}$

Finally, surgical operations should not be attempted in centers having no experience in craniotomy and vascular operations because the anterior fossa contains major vessels and cranial nerves. Such procedures can lead to various unexpected fatal complications and morbidity. Although the entry point of the nail in this case was on the infraorbital region, the optic nerve, internal carotid artery and branches were intact, and the neurological examination was normal except for a weak pupillary light reflex on the left side. The periorbital tissue and osseous part of the orbital roof were injured. After physical examination and radiological investigations, we considered that immediate surgical intervention would be more reliable, given the finding that the nail had not seriously damaged any neurovascular structures at the moment of entry. In this case, we did not perform cerebral angiography preoperatively because the patient had no neurological or radiological abnormalities. While we decided not to perform angiography in this patient, we nevertheless believe that this procedure is absolutely necessary in these types of injuries.

In conclusion, penetrating injuries with construction nails are uncommon but life-threatening injuries. Appropriate imaging studies include CT scan of the head, with or without angiography, and therapeutic embolization. Neurosurgical and otolaryngologic approaches are most commonly used to extract these foreign bodies from the face, skull base and parenchyma. Appropriate diagnosis is crucial to avoid potential complications such as CSF leakage, intracra- nial infection and hemorrhage. Thorough knowledge of the neuro-anatomic relationships within the injured region is the most important criterion in such procedures. We believe that physicians should not attempt to remove foreign bodies and should refer the patient to neurosurgeons who are experienced in neurovascular surgery. In addition, medical precautions such as antibiotherapy and tetanus prophylaxis should not be neglected. Families in developing countries should be taught how to limit accidents and to protect children from danger.

\section{REFERENCES}

1. Agrillo A, Sassano P, Mustazza MC, Filiaci F. Complex-type penetrating injuries of craniomaxillofacial region. J Craniofac Surg 2006; 17:442-6.

2. Bilotta F, Rosa G, Delfini R, Pinto R, Fiorani B. Unrecognized periorbital penetrating nail in the brain: case report. Am J Emerg Med 2007;25:198-9.

3. Bragg S. Head trauma from a nail gun. J Emerg Nurs 2006;32:329.

4. Lee $\mathrm{AD}, \mathrm{Oh} \mathrm{YS}$. Unusual delayed presentation of a nail gun injury through the skull base. Laryngoscope 2007;117:977-80.

5. Panourias IG, Slatinopoulos VK, Arvanitis DL. Penetrating craniocerebral injury caused by a pneumatic nail gun: an unsuccessful attempt of suicide. Clin Neurol Neurosurg 2006;108:490-2.

6. Türkçüoğlu P, Aydoğan S. Intracranial foreign body in a globe-perforating injury. Can J Ophthalmol 2006;41:504-5.

7. Selvanathan S, Goldschlager T, McMillen J, Campbell S. Penetrating craniocerebral injuries from nail-gun use. J Clin Neurosci 2007;14:678-83.

8. Chibbaro S, Tacconi L. Orbito-cranial injuries caused by penetrating non-missile foreign bodies. Experience with eighteen patients. Acta Neurochir (Wien) 2006;148:937-42.

9. Cosan TE, Arslantas A, Guner AI, Vural M, Kaya T, Tel E. Injury caused by deeply penetrating knife blade lodged in infratemporal fossa. Eur J Emerg Med 2001;8:51-4.

10. Buchalter GM, Johnson LP, Reichman MV, Jacobs J. Penetrating trauma to the head and neck from a nail gun: a unique mechanism of injury. Ear Nose Throat J 2002;81:779-83.

11. Nitsch A, Verheggen R, Merten HA. Penetrating pneumatic nail-gun injury to skull base. Br J Oral Maxillofac Surg 2007;45:692.

12. Gonzalez LF, Crawford NR, Horgan MA, Deshmukh P, Zabramski JM, Spetzler RF. Working area and angle of attack in three cranial base approaches: pterional, orbitozygomatic, and maxillary extension of the orbitozygomatic approach. Neurosurgery 2002;50:550-7.

13.Zabramski JM, Kiriş T, Sankhla SK, Cabiol J, Spetzler RF. Orbitozygomatic craniotomy. Technical note. J Neurosurg 1998;89:336-41. 